Original Research Paper

\title{
The Perceptions of Local Community's About Diversity of Mangrove Ecological Potential for Ecotourism Development in the South Coast of Lombok Island, Indonesia
}

\author{
Lalu Raftha Patech $^{1 *}$, Kumala Ratna Dewi ${ }^{1}$, Zulhalifah $^{1}$, Abdul Syukur ${ }^{1}$, Jamaluddin ${ }^{1}$ \\ ${ }^{1}$ Magister of Natural Sciences Education, Postgraduate University of Mataram, Mataram, Indonesia
}

\author{
Article History \\ Received : June $04^{\text {th }}, 2021$ \\ Revised : June $21^{\text {th }}, 2021$ \\ Accepted : June $26^{\text {th }}, 2021$ \\ Published : July $03^{\text {th }}, 2021$ \\ *Corresponding Author: \\ Lalu Raftha Patech, \\ Magister of Natural Sciences \\ Education, Postgraduate \\ University of Mataram, \\ Mataram, Indonesia \\ Email: \\ laluraftapateh31@gmail.com
}

\begin{abstract}
The utilization of the coastal environment is still dominated byproducts and has not yet switched to ecosystem service products, such as the use of mangrove ecosystems as ecotourism. This study aims to assess the local community's perception of the potential diversity that becomes an object for the community's economy. The research method uses surveys, observations, and interviews for social data, while the ecological data use transect and quadratic methods. Furthermore, data analysis used descriptive statistics. In addition, ecological data were analyzed using density $(K i)$, relative frequency $(F R)$, diversity $\left(\mathrm{H}^{\prime}\right)$ of mangroves, and ecological indexes (Diversity $\left(\mathrm{H}^{\prime}\right)$, Evenness (E), Dominance (D)). The results of the study found six mangrove species, ten echinoderm species, and thirteen bivalves. The highest diversity index $\left(\mathrm{H}^{\prime}\right)$ was in Poton Bako 1.80 and the Evenness index ranged from $0.80-$ 0.98 with a stable category. Biota relative dominance the association index of echinoderms is high 0.79-0.11. Meanwhile, the bivalves Dominance index of 0.03-0.11 was low. In addition, local community's perception of mangrove conservation for ecotourism, $63 \%$ of the community stated, $7 \%$ is not possible and $30 \%$ is not. The feasible value of mangrove development is $62 \%, 17 \%$ is not feasible and $21 \%$ does not know. The priority developed by Eduwisata is $48 \%$, Bird Watching is $20 \%$ and Tracking is $32 \%$. The conclusion is that the choice of using mangrove ecosystem services can be developed as a policy in overcoming economic threats and the vulnerability of marine biota as well as solutions for local communities.
\end{abstract}

Keywords: Perception; Conservation; Mangrove; Ecotourism.

\section{Pendahuluan}

Ekosistem mangrove adalah suatu pola ekosistem yang membentuk struktur komunitas yang khas (Agil et al., 2014). Hal ini disebabkan ekosistem mangrove terbentuk dari gabungan empat anasir dasar, yaitu tumbuhan, hewan, tanah dan air (Agil et al., 2014). Ekosistem mangrove termasuk ekosistem peralihan antara darat dan laut (Castro et al., 2014; Karimah, 2017). Mangrove bersifat sangat kompleks dan dinamis, tetapi labil (Julaikha et al., 2017). Mangrove dikatakan kompleks karena ekosistemnya dipenuhi vegetasi mangrove dan habitat berbagai satwa dan biota laut (Heriyanto et al., 2012). Ekosistem mangrove di daerah pantai yang terlindungi dan menjadi pendukung berbagai jasa ekosistem (Senoaji et al., 2016).

Jasa ekologi mangrove adalah sebagai rumah bagi keanekaragaman hayati seperti biota asosiasi
Echinodermata dan bivalvia, burung, ular, mamalia, kepiting, spons, tunicates dan berfungsi untuk menyerap nutrisi dan sedimen yang mengalir dari sungai, memberikan perlindungan dari gelombang dan badai serta berfungsi sebagai tempat pembibitan, pemijahan dan pemeliharaan dari banyak spesies laut untuk (Ellison, 2008; Nagelkerken et al., 2008; Cannicciet al., 2008; Malik et al., 2017). Jasa lingkungan dari ekosistem mangrove sebagai pelestarian biodiversity, kenyamanan dan keindahan (Agil et al., 2018; Sandifer et al., 2015). Jasa lingkungan lainnya adalah sebagai regulasi gas (gas regulation) untuk keseimbangan $\mathrm{CO}_{2}$ dan $\mathrm{O}_{2}$ di atmosfer, regulasi iklim (climate regulation), sumber genetik (genetic resources), pengatur dinamika trofik spesies dan populasi (biological control) serta meningkatkan nilai biodiversity (Larkum et al., 2006; Agil et al., 2018; Khan et al., 2019). 
Ekosistem mangrove dapat menjadi kawasan objek ekowisata (Arsad et al, 2021). Ekowisata bertujuan untuk mempertahankan ekosistem mangrove dengan cara konservasi dan menjadikan ekosistem mangrove sebagai tempat wisata (Yuliana \& Supriono, 2020). Sementara itu, pengembangan ekowisata telah menjadi perhatian besar, khususnya untuk kelestarian sumber daya alam, seperti mangrove (Lelloltery et al, 2021). Dalam hal ini, ekowisata berfungsi untuk melestarikan sumber daya alam dan lingkungan.

Pemanfaatan lingkungan untuk kegiatan ekowisata sesuai dengan tujuan konservasi (Friess et al, 2020; Christian et al, 2021). Selain itu memiliki peran sebagai sumber ekonomi masyarakat lokal (Litioly et al, 2020). Namun demikian, tantangannya adalah kebiasaan dan pengetahuan masyarakat lokal yang belum mendukung dalam pemanfaatan ekosistem mangrove untuk kegiatan ekowisata (Dewi et al, 2021; Harto et al, 2021). Sementara itu, ekowisata dapat menjadi instrumen dalam konservasi, pendidikan atau sumber belajar dan perluasan kawasan mangrove (Hakim et al., 2017; Friess, 2017; Massieng et al., 2020).

Kabupaten Lombok Timur memiliki panjang pantai $220 \mathrm{~km}$ dan memiliki hutan mangrove dengan luas $1.589,81$ ha termasuk didalamnya mangrove pesisir pantai selatan lombok timur (Idrus et al, 2018). Potensi ekologi mangrove kecamatan keruak ditemukan sebanyak 10 spesies mangrove, kecamatan jerowaru 8 spesies mangrove dan keragaman makroinvertebrata seperti moluska serta kepiting bakau (Tahmid et al, 2015; Idrus et al, 2018; Candri et al, 2020). Selain itu, aspek ekologi spesies mangrove dapat menyerap karbon dan menjadi bioindikator untuk menilai akumulasi tingkat pencemaran suatu perairan dari logam berat (Khairuddin et al., 2018; Zulhalifah et al, 2021). Lebih lanjut, keberadaan mangrove di lokasi studi telah menjadi sumber mata pencaharian masyarakat lokal (Syukur et al, 2020). Namun demikian, potensi ekologi mangrove di lokasi studi dikembangan untuk kegiatan ekowisata. Oleh karena itu, perlu dilakukan penelitian tentang persepsi masyarakat untuk pengembangan potensi ekologi mangrove sebagai ekowisata. Tujuan penelitian ini menilai persepsi dan potensi ekologi mangrove untuk pengembangan ekowisata. Manfaat penelitian ini adalah dapat menjadi sumber informasi ilmiah untuk konservasi mangrove berbasis pengembangan ekowisata, dan sebagai sumber kebijakan pengelolaan keberlanjutan ekosistem mangrove untuk perlindungan lingkungan dan ekonomi masyarakat lokal, khususnya di lokasi studi dan lokasi lainnya

\section{Bahan dan Metode}

\section{Lokasi Penelitian}

Penelitian dilaksanakan pada bulan Maret - Juni 2021 di kawasan hutan mangrove Lungkak dan Poton Bako, Kabupaten Lombok Timur dan Awang, Kabupaten Lombok Tengah (Gambar 1).

\section{Pengambilan dan Analisis Data}

Data dalam penelitian ini dikumpulkan melalui survei dan observasi. Selanjutnya pendataan dibagi menjadi dua tahap, pertama pendataan sosial terhadap persepsi masyarakat lokal tentang pengembangan ekowisata, dan kedua pendataan ekologi mangrove (seperti kondisi lingkungan, parameter, spesies mangrove, dan keanekaragaman, keseragaman, dan dominansi mangrove beserta biota asosiasinya.

\section{1) Data Sosial}

Pengambilan data sosial dilakukan dengan metode diskusi secara mendalam/Focus Group Discussion, dan wawancara tentang persepsi masyarakat lokal dan pelaku ekowisata (operator dan wisatawan). Kriteria responden sebagai informan dalam penelitian ini berbeda untuk setiap kelompok. Operator sebagai responden dengan kriteria adalah mereka yang memiliki pengalaman sebagai operator wisata pantai di lokasi penelitian minimal 5 tahun. Sedangkan masyarakat lokal sebagai responden memiliki kriteria sebagai berikut: (1) Terdaftar sebagai anggota masyarakat dan berdomisili di desa masingmasing lokasi penelitian dan (2) Berusia minimal 25 $\geq$ tahun. Selanjutnya, kelompok wisatawan adalah responden. Selain ketiga kelompok responden, dalam penelitian ini juga digunakan tokoh masyarakat dan/atau tokoh formal sebagai informan kunci. Peneliti biasanya mengumpulkan data, menggunakan kuesioner dan diskusi mendalam. Selanjutnya metode yang digunakan adalah purposive sampling dan jumlah responden dari masingmasing kelompok ditentukan secara proporsional. Semua data yang diperoleh dari responden dianalisis menggunakan statistik deskriptif.

\section{2) Data Ekologi}

Pengumpulan data ekologi mangrove (seperti kondisi lingkungan, parameter, spesies mangrove, dan biota asosiasinya) dengan menggunakan analisis kerapatan dan frekuensi mangrove $(\mathrm{Ki}$, dan $\mathrm{Fr}$ ), Keanekaragaman dengan menggunakan Indeks Shannon-Wiener (H'), Keseragaman menggunakan indeks Evenness (E), dan Dominansi mangrove beserta biota asosiasinya menggunakan Indeks Simpson (D). Selanjutnya, analisis kerapatan jenis mangrove, menggunakan rumus kerapatan dan frekuensi relatif dengan persamaan (Kodri, 2012):

$$
\mathrm{K}=\frac{\text { Jumlah individu }}{\text { Luas petak pengamatan }}
$$




$$
\begin{aligned}
\mathrm{K}-\mathrm{i} & =\frac{\text { Jumlah individu untuk spesies ke }-\mathrm{i}}{\text { Luas petak pengamatan }} \\
\mathrm{KR}-\mathrm{i} & =\frac{\text { Kerapatan spesies } \mathrm{ke}-\mathrm{i}}{\text { Kerapatan Seluruh spesies }} \times 100 \%
\end{aligned}
$$

Frekuensi Relatif $(\%)=\frac{\text { Frekuensi jenis } k e-i}{\text { frekuensi seluruh jenis }} \times 100 \%$

Analisis indeks keanekaragam mangrove, Echinodermata, dan bivalvia, keanekaragaman menunjukkan keragaman spesies atau proporsi jumlah spesies dengan jumlah individu/spesies dalam komunitas, menggunakan rumus indeks Diversity Shannon dan Wiener, dengan Persamaan (Sulistiyowati, 2019):

Keterangan:

$$
\mathrm{H}^{\prime}=-\sum P i \ln P i, \operatorname{dimana} P i=\frac{n i}{N}
$$

$$
\begin{array}{ll}
\mathrm{H}^{\prime} & =\text { Indeks Keanekaragaman } \\
\mathrm{ni} & =\text { Jumlah individu jenis ke }-1 \\
\mathrm{~N} & =\text { Jumlah individu total }
\end{array}
$$

dimana, H' adalah indeks keanekaragaman ShannonWiener, s adalah jumlah jenis, pi adalah proporsi individu bertipe-i terhadap jumlah individu $(\mathrm{pi}=\mathrm{ni} / \mathrm{N})$, ni adalah jumlah individu bertipe, $\mathrm{N}$ adalah total individu dari semua spesies.

\section{Keseragaman Echinodermata dan Bivalvia}

Analisis kesamaan distribusi individu dari setiap spesies Echinodermata dan bivalvia, menggunakan analisis indeks Evenness, dengan rumus:
$\mathrm{E}=$ Indeks Evenness

$$
E=\frac{H^{\prime}}{\log S_{2}}
$$

$\mathrm{H}^{\prime}$ = Nilai Indeks Keanekaragaman

$\log S_{2}=$ jumlah spesies

dimana, E' adalah indeks kemerataan, H' adalah nilai indeks keanekaragaman dan $\mathrm{S}$ adalah jumlah spesies yang berhasil diambil sebagai contoh.

\section{Dominansi Echinodermata dan Bivalvia}

Indeks dominansi dihitung dengan menggunakan indeks dominansi dari Simpson (Odum, 1996): dengan rumus:

$$
D=1-\frac{\sum n(n-1)}{N(N-1)}
$$

$$
\begin{aligned}
\mathrm{D} & =\text { Indeks Dominansi } \\
n i & =\text { Jumlah individu jenis- } i \\
\mathrm{~N} & =\text { Jumlah total individu }
\end{aligned}
$$

Indeks dominansi berkisar antara 0 sampai 1 , dimana semakin kecil nilai indeks dominansi maka menunjukan bahwa tidak ada spesies yang mendominasi sebaliknya semakin besar dominansi maka menunjukkan ada spesies tertentu (Odum, 1996)

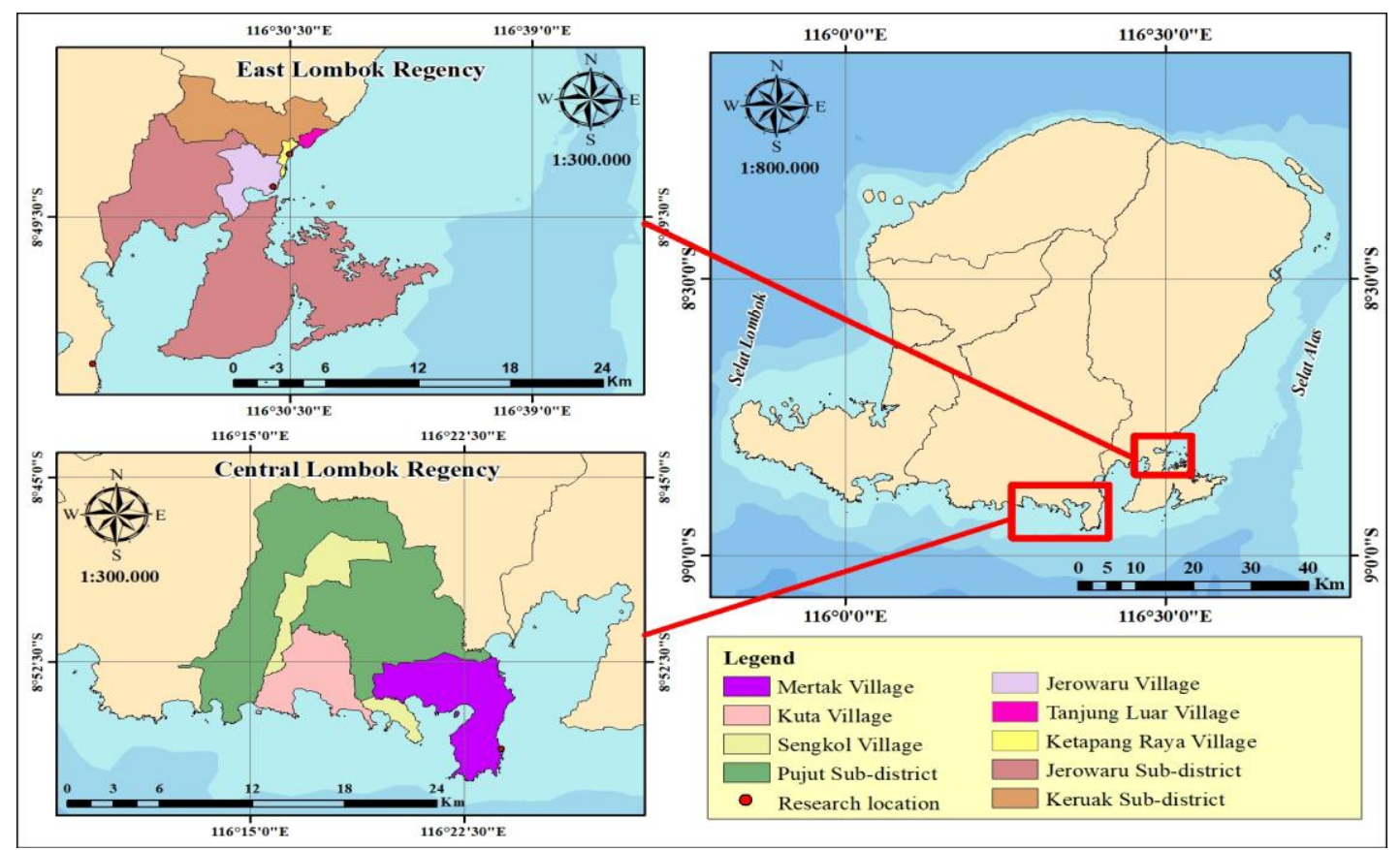

Gambar 1. Peta Lokasi Penelitian 


\section{Hasil dan Pembahasan}

\section{Potensi Ekologi Mangrove}

\section{1) Kerapatan Spesies Mangrove}

Indikator ekosistem mangrove adalah ditemukannya spesies mangrove di suatu kawasan mangrove. Jumlah total spesies mangrove yang ditemukan di tiga lokasi penelitian terdapat enam spesies mangrove yang terdiri dari Avicennia marina, Ceriops decandra, Rhizophora mucronata, Rhizophora stylosa, Sonneratia alba, dan Xylocarpus moluccensis (Gambar 2). Kerapatan spesies mangrove tertinggi di Lungkak adalah Avicennia marina $(94.53 \%)$ dan terendah Xylocarpus moluccensis dan Ceriops decandra (1.37\%) (Gambar 2).

Tingginya kerapatan Avicennia marina di Lungkak disebabkan karena drainase tempat tumbuh jenis-jenis mangrove di lokasi tersebut kurang bagus. Ketika terjadi pasang rendah, air laut yang terdapat pada lokasi ini sangat lambat untuk kembali ke laut. Penggenangan yang lama mengakibatkan mangrove sulit untuk menghilangkan kelebihan garam. Kondisi tersebut pertumbuhan jenis-jenis mangrove yang tidak toleran kadar garam tinggi dan membutuhkan banyak oksigen menjadi terhambat. Kondisi lingkungan yang berkadar garam tinggi merupakan habitat yang paling cocok untuk pertumbuhan Avicennia marina. Hal tersebut didukung oleh Kitamura (1997) dan diperkuat hasil penelitian Agil (1998) dan Agil et al (2017). Hasil pengumpulan data di lapangan menunjukkan jenis tumbuhan mangrove tingkat semai yang terdapat di Lungkak ada 4 jenis dan jenis paling dominan adalah Avicennia marina. Adanya perbedaan yang sangat tinggi mengindikasikan hanya semai Avicennia marina paling mampu beradaptasi pada lingkungan berkadar garam tinggi di Lungkak.

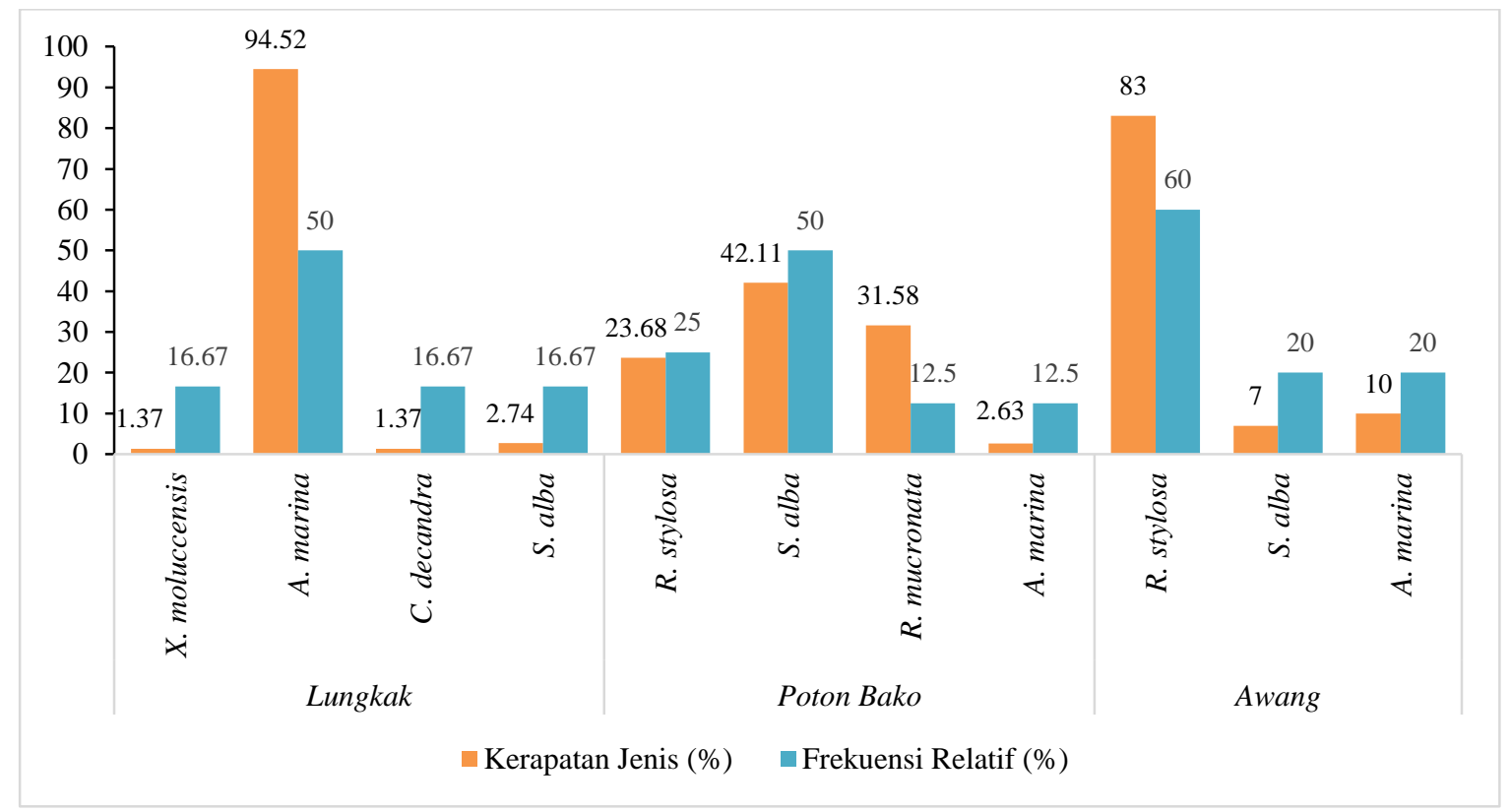

Gambar 2. Kerapatan Jenis (\%) dan Frekuensi Relatif (\%) di Lungkak, Poton Bako dan Awang

Mangrove yang terdapat di Poton Bako tumbuh alami dan ditanam masyarakat. Menurut informasi masyarakat, pada zaman dahulu hutan mangrove di kawasan ini paling bagus tegakannya dan paling lebat dibanding lokasi lain di Lombok Timur. Penebangan liar menjadi penyebab kerusakan ekosistem mangrove. Kerusakan tersebut mengakibatkan sering terjadi bencana seperti gempuran ombak pada saat pasang dan tiupan angin kencang banyak menimbulkan kerusakan perumahan penduduk. Menyadari penyebab bencana tersebut, masyarakat dengan dibantu pemerintah menghijaukan kembali mangrove di Poton Bako. Jenisjenis yang tumbuh alami tetap dikonservasi dan jenis yang telah hilang didatangkan kembali.
Kerapatan spesies mangrove tertinggi di Poton Bako adalah Sonneratia alba (42.11\%) dan terendah Avicennia marina (2.63\%). Selanjutnya, frekuensi relatif tertinggi adalah Sonneratia alba (50\%) dan terendah Avicennia marina (12.5\%). Kehadiran Sonneratia alba yang menjadi paling dominan di Poton Bako ini ditunjang substrat yang cocok, yaitu tumbuh baik pada pasir berlumpur. Faktor lain yang juga berpengaruh terhadap pertumbuhan jenis tersebut karena pada lokasi penelitian terjadinya pasang surut berlangsung secara rutin. Hal tersebut membantu dalam pencucian garam yang berlebih pada lingkungan mangrove.

Sonneratia alba tumbuh alami di Poton Bako, umumnya berupa pohon-pohon besar. Sonneratia alba 
jenis mangrove yang paling luas sebarannya dengan ukuran diameter batang paling besar. Pertumbuhan Sonneratia alba di Poton Bako telah mencapai klimaks. Beberapa individu banyak yang mulai mengalami pelapukan batang dan tumbang. Mangrove anggota Rhizophoraceae yaitu Rhizophora stylosa dan Rhizophora mucronata umumnya ditanam masyarakat di Poton Bako. Kedua jenis mangrove tersebut menunjukkan kerapatan yang cukup tinggi pada lokasi penelitian dan dengan pertumbuhan yang bagus. Pertumbuhan Rhizophora stylosa dan Rhizophora mucronata didukung kondisi lingkungan, yaitu tumbuh pada elevasi rendah pada substrat lumpur berpasir. Kondisi ini didukung oleh Kitamura (1997) yang diperkuat Agil (2014).

Selain itu, faktor drainase yang baik (tidak terjadi penggenangan air yang lama) yang membantu proses pencucian garam yang sangat diperlukan. Hasil pengamatan di lapangan menunjukkan bahwa mangrove tingkat pancang Rhizophora stylosa dan Rhizophora mucronata umumnya cenderung tumbuh pada lokasi yang elevasinya lebih rendah dari posisi tumbuhan induk yang ditanam masyarakat. Elevasi lebih rendah terletak ke arah formasi depan menuju laut (menjauhi garis pantai). Kondisi ini alamiah terjadi karena sifat kedua jenis tersebut seperti yang dilaporkan Agil (2014) dan Kitamura (1997).

Kerapatan spesies mangrove tertinggi di Awang adalah Rhizophora stylosa (83\%) dan terendah Sonneratia alba (7\%). Tingginya kerapatan jenis Rhizophora stylosa karena memiliki jumlah individu yang lebih banyak. Selain itu, habitat didominasi oleh pasir, pasir berlumpur dan lumpur berpasir. Semakin banyak jumlah individu yang diperoleh, maka nilai kerapatan semakin tinggi.
Selain itu, factor drainase yang baik membantu proses pencucian garam yang diperlukan jenis ini.

\section{2) Frekuensi Spesies Mangrove}

Frekuensi kehadiran jenis mangrove dipengaruhi oleh banyaknya jumlah suatu jenis yang ditemukan pada setiap plot. Semakin banyak jumlah plot ditemukannya jenis mangrove, maka nilai frekuensi relatif mangrove semakin tinggi. Frekuensi relatif tertinggi di Lungkak adalah Avicennia marina (50\%) dan terendah Xylocarpus moluccensis, Ceriops decandra (1.37\%) (Gambar 2). Selanjutnya, frekuensi relatif tertinggi di Poton Bako adalah Sonneratia alba (50\%) dan terendah Avicennia marina, Rhizophora mucronata (1.25\%) (Gambar 2). Sedangkan frekuensi relatif tertinggi di Awang adalah Rhizophora stylosa (60\%) dan terendah Avicennia marina, Sonneratia alba (20\%) (Gambar 2). Tingginya nilai frekuensi pada salah satu jenis mangrove disebabkan karena ditemukannya pada setiap transek penelitian. Selain itu, faktor lingkungan mendukung pertumbuhan jenis mangrove dibandingkan dengan jenis lain.

\section{3) Indeks Keanekaragaman Mangrove}

Nilai keanekaragaman suatu komunitas sangat bergantung pada jumlah jenis dan jumlah individu yang terdapat pada komunitas tersebut. Keanekaragaman jenis suatu komunitas akan tinggi jika komunitas itu disusun oleh banyak jenis dan tidak ada spesies yang mendominasi. Sebaliknya, suatu komunitas memiliki nilai keanekaragaman jenis yang rendah, jika komunitas itu disusun oleh sedikit jenis dan ada spesies yang dominan (Indriyanto, 2006).

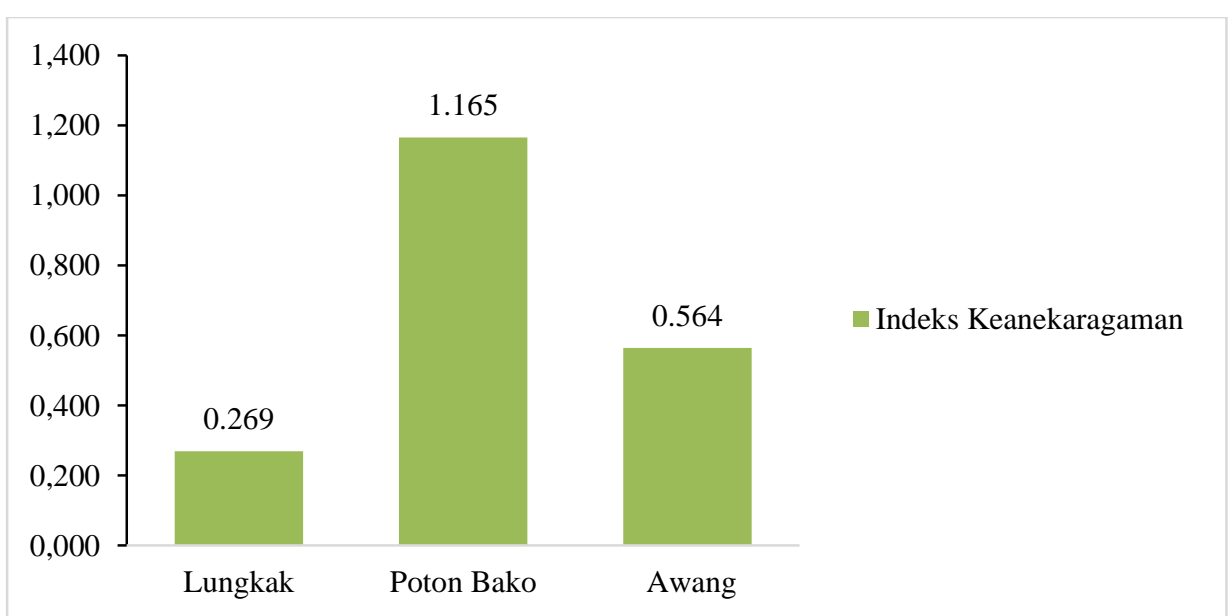

Gambar 3. Indeks Keanekaragaman Shannon-Wiener

Indeks keanekaragaman mangrove tertinggi ada di kawasan Poton Bako dengan kategori sedang (1.165). Jika dibandingkan dengan indeks keanekaragaman yang terdapat di Awang dengan kategori rendah (0.564) dan
Lungkak (0.269) (Gambar 3). Tingginya indeks keanekaragaman di Poton Bako disebabkan keseragaman spesies di lokasi tersebut tinggi dan tidak ada yang menodminasi. Berbeda dengan kawasan Lungkak dan Awang yang memiliki keseragaman spesies yang rendah. 
Hal ini dapat dilihat pada (Gambar 2) dimana pada kawasan Awang didominasi oleh Rhizophora stylosa, kemudian pada kawasan Lungkak didominasi oleh Avicennia marina. Rendahnya keseragaman pada kawasan Awang dan Lungkak menyebabkan rendahnya indeks keanekaragaman.

\section{4) Komposisi Echinodermata di Lokasi penelitian}

Echinodermata berasal dari bahasa Yunani Echinos artinya duri, dan derma artinya kulit. Secara umum Echinodermata berarti hewan yang berkulit duri. Echinodermata terbagi atas 5 kelas yaitu kelas Asteroidea, Echinoidea, Holothuroidea, Ophiuroidea dan Crinoidea. Keberadaan echinodermata pada padang lamun sebagai habitat kompleks dan sangat penting bahkan bagi spesies lain seperti bivalvia, crustacea, cephalopoda, siput, dan ikan (Lowery, J.L. et al, 2007). Echinodermata disebut sebagai kunci ekologi yang berperan dalam menjaga keseimbangan ekosistem laut, termasuk ekosistem lamun yang merupakan salah satu habitat bagi Echinodermata (Raghunathan, 2012). Secara ekologi Echinodermata berperan sangat penting di ekosistem lamun, terutama dalam rantai makanan (food web) (Hermosillo-Núñez, B.
B. 2020). Echinodermata adalah spesies yang mencolok di ekosistem pesisir dan laut, dan dalam banyak kasus, mereka memiliki peran ekologis dalam struktur komunitas, bertindak sebagai yang predator teratas dan pemakan bentik (Ortiz \& Levins, 2011; Steneck et al., 2018). Selain itu, mereka berkontribusi pada proses bioerosion, rekrutmen dan transfer energi di ekosistem laut (Bronstein \& Loya, 2014), dan beberapa di antaranya sebagai sumber daya yang penting secara ekonomi (Claoue 'et al., 1988).

Hasil penelitian di Pesisir Pantai Lungkak, Poton Bako dan Awang diperoleh secara keseluruhan 10 spesies dari filum Echinodermata yang terdiri dari 3 kelas seperti disajikan pada Tabel 1. Spesies Mespilia globulus, Diadema setosum dan Tripneustes gratilla adalah spesies yang paling banyak ditemukan dan spesies Synapta maculata, Holothuria leucospilota, Echinothrix diadema, dan Holothuria atra adalah spesies yang rata-rata paling sedikit ditemukan di Lokasi penelitian. Jumlah spesies Echinodermata di lokasi penelitian lebih rendah dari jumlah spesies Echinodermata di Perairan Pesisir Pantai Selatan Lombok Timur 14 Spesies (Patech et al., 2020). Namun sama dengan di Babanlagan Philipina yang hanya 10 spesies Echinodermata (Llacuna et al., 2016).

Tabel 1. Jenis Echinodermata yang ditemukan di Lokasi penelitian

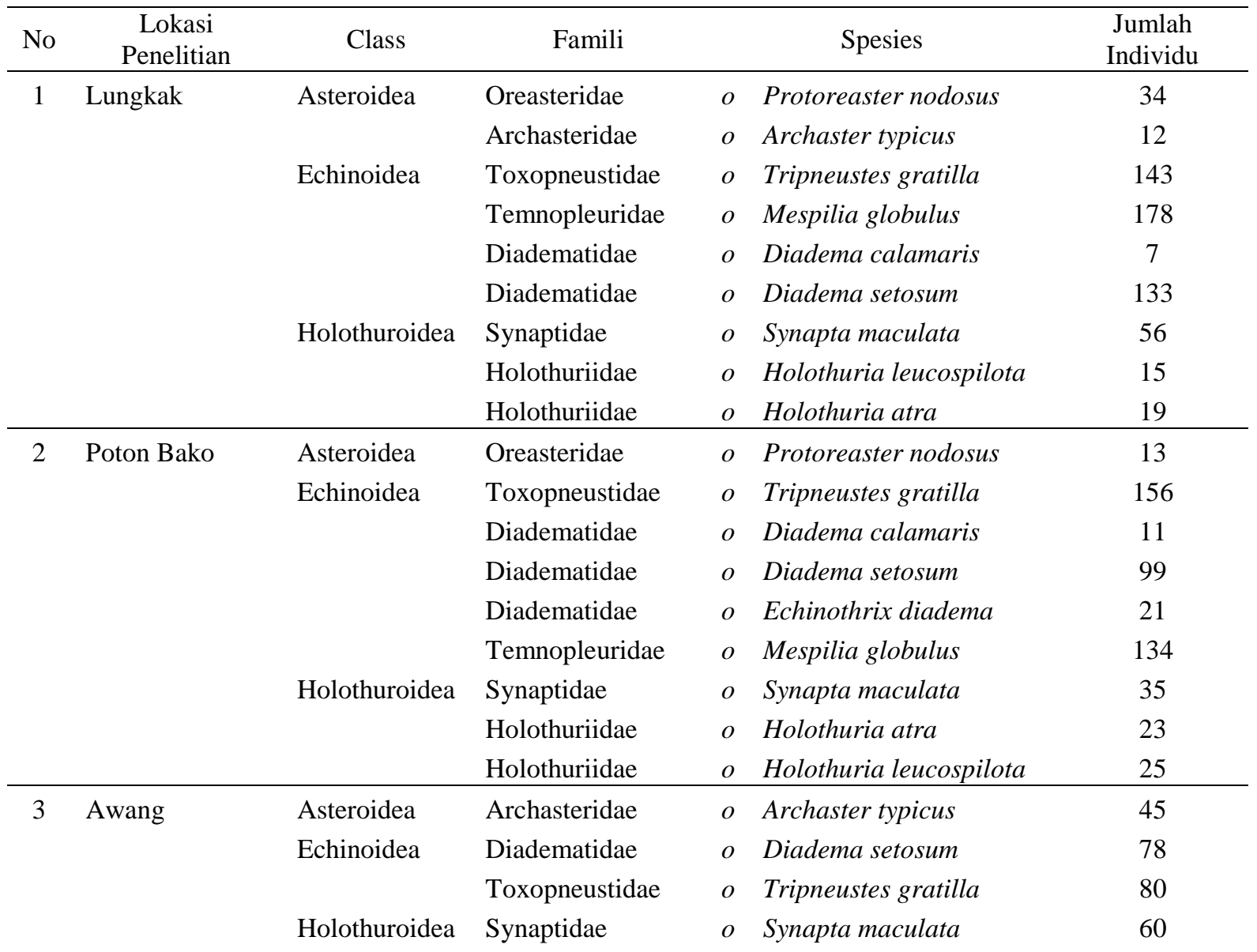




\section{5) Indeks Ekologi Echinodermata}

Indeks keanekaragaman (H') yang terdapat di ekosistem mangrove di Lungkak, Poton Bako, dan Awang tergolong Rendah. Indeks keseragaman di ketiga Lokasi Penelitian (E) tergolong stabil dan indeks dominansi (D) tergolong tinggi. Semakin tinggi nilai H' maka semakin tinggi variasi spesies pada suatu wilayah. Indeks keanekaragaman sangat dipengaruhi oleh jumlah spesies dan individu (Odum, 1996). Ketiga nilai indeks tersebut disajikan pada Gambar 4.

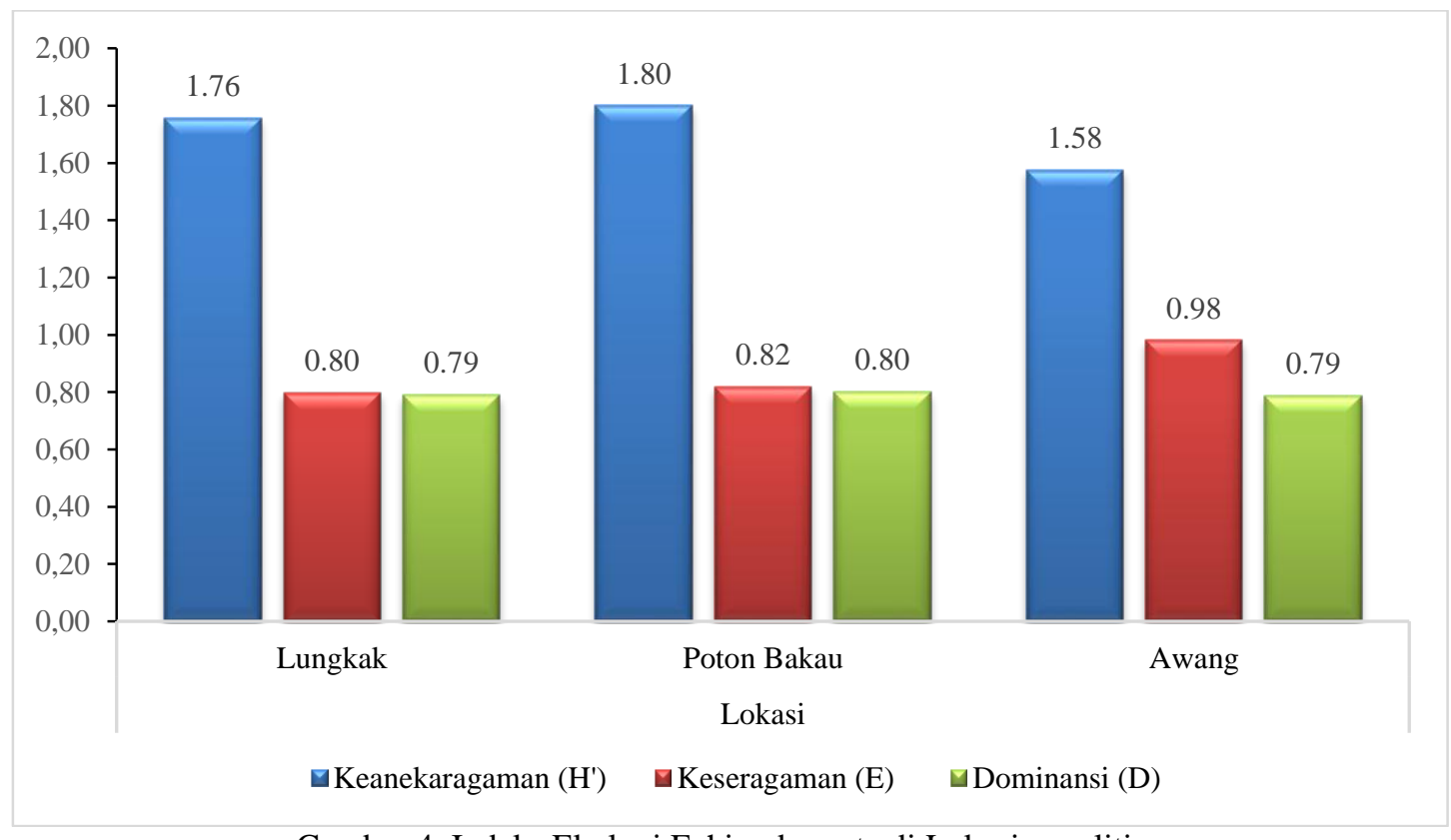

Gambar 4. Indeks Ekologi Echinodermata di Lokasi penelitian

Berdasarkan perhitungan indeks keanekaragaman (H') diperoleh keanekaragaman tertinggi terdapat di Pantai Poton Bako dengan nilai 1.80, Lungkak 1.76 dan yang terendah di Awang dengan Nilai Keanekaragaman 1,58. Berbeda dengan yang dilaporkan Patech et al (2020) di Perairan Pesisir Pantai Selatan Lombok Timur rata-rata Keanekaragaman Echinodermata yakni 1.48 yang tergolong rendah, dan di Perairan Pesisir Pantai Selatan Lombok Tengah (Bahri et al., 2021) rata-rata Keanekaragaman Echinodermata yakni 1.92 yang juga tergolong rendah. Indeks keseragaman (E) tertinggi di Pantai Awang dengan nilai 0,98 sehingga tergolong kategori tinggi. Indeks dominansi relatif diperoleh dominansi tertinggi di Pantai Poton Bako dengan nilai 0,82 yang tergolong kategori tinggi yang berarti ada jenis yang mendominasi seperti Tripneustes gratilla, Mespilia globulus, dan Diadema setosum.

Nilai indeks Keseragaman (E) menunjukkan pola sebaran individu pada suatu lokasi. Jika indeks keseragamannya semakin besar maka pola sebaran individu pada suatu lokasi merata, sebaliknya jika nilai indeks keseragamannya semakin kecil menujukkan pola sebaran individu yang tidak merata. Nilai indeks keseragaman yang diperoleh di lokasi penelitian adalah berkisar antara 0,80 - 0,98 dan termasuk dalam kategori stabil. Nilai indeks keseragaman yang diperoleh dari ketiga lokasi penelitian menunjukkan bahwa pola sebaran spesies pada lokasi penelitian cukup merata yang menunjukkan bahwa komunitas pada kondisi stabil.

Berdasarkan hasil pengolahan data Indeks Dominansi (D) relatif diperoleh nilai tertinggi di Pantai Poton Bako dengan nilai 0.80, sedangkan Lungkak dan Awang 0.79 yang tergolong kategori tinggi yang berarti ada jenis yang mendominasi. Apabila indeks dominansi relatif mendekati 1 berarti ada salah satu spesies yang mendominasi dan biasanya diikuti dengan indeks keanekaragaman rendah begitu juga sebaliknya (Lina, 2015). Tingginya indeks dominansi Echinodermata di ketiga lokasi penelitian berkaitan dengan nilai indeks keanekaragaman $\left(\mathrm{H}^{\prime}\right)$ dan indeks keseragaman (E). Odum (1996) menjelaskan nilai $\mathrm{H}^{\prime}$ dan $\mathrm{E}$ bersifat berbanding terbalik terhadap nilai D. Jika nilai $\mathrm{H}^{\prime}$ dan E tinggi maka nilai D akan rendah, sebaliknya jika nilai D tinggi maka nilai $H^{\prime}$ dan $E$ akan rendah. Nilai indeks dominansi Simpson (D) Echinodermata di ketiga lokasi penelitian termasuk dalam kategori tinggi. Nilai tersebut menunjukkan bahwa adanya dominansi suatu jenis dalam ekosistem. Nilai indeks dominansi yang mendekati 1 
menunjukkan adanya spesies yang mendominasi spesies lainnya. Sedangkan nilai indeks dominansi yang mendekati 0 menunjukkan hampir tidak ada dominansi dari suatu spesies dalam komunitas (Smith dan Smith, 2011).

Kekayaan dari Indeks Ekologis ini dimanfaatkan oleh masyarakat lokal untuk berburu biota laut yang disebut dengan tradisi "madak" masyarakat sekitar pantai, dan juga berpengaruh pada sektor kunjungan wisatawan karena menurut masyarakat lokal bahwa echinodermata ini dianggap menarik oleh para wisatawan karena bentuknya khas "berkulit duri" (Echinoidea), "timun laut" (Holothuroidea), dan berbentuk bintang "Asteroidea" sehingga dapat menjadi sarana aktivitas Eduwisata.

\section{6) Komposisi Bivalvia di Lokasi penelitian}

Pelecypoda (Bivalvia) adalah kelas dalam filum Moluska, termasuk semua kerang (Allen, 2013). Hasil penelitian spesies kerang di lokasi penelitian sebanyak 15 spesies (Tabel 2). Jumlah bivalvia yang ditemukan pada penelitian ini lebih banyak dibandingkan dengan bivalvia yang ditemukan pada survei di Pulau Pannikiang, Kabupaten Barru, sebanyak 14 spesies (Alfiansyah et al, 2014). Sedikitnya jumlah jenis dan jumlah individu yang ditemukan pada masing-masing stasiun disebabkan karena terjadinya eksploitasi (Provisioning services) oleh masyarakat setempat dalam jumlah yang besar dengan intensitas eksploitasi yang tak terkendalikan khususnya bagi bivalvia yang memiliki nilai ekonomis tinggi (Akhrianti, 2014; Alfiannur et al., 2018).

Adanya keanekaragaman jenis bivalvia di lokasi penelitian merupakan bukti adanya keterkaitan bivalvia dengan ekosistem mangrove. Disamping itu dapat menjadi indikator ekologi fungsi mangrove sebagai habitat bivalvia. Disamping itu, Bivalvia memberikan jasa kultural (Cultural services) yakni cangkangnya dapat dijadikan aksesoris yang sering diperjualbelikan di pesisir pantai dalam bentuk gelang/perhiasan (dalam Bahasa masyarakat lokal di lokasi penelitian adalah "keke") sehingga dapat menjadi salah satu daya dukung dalam sektor pariwisata, sekaligus sebagai tambahan pendapatan masyarakat lokal.

Tabel 2. Famili dan spesies bivalvia di Lokasi penelitian

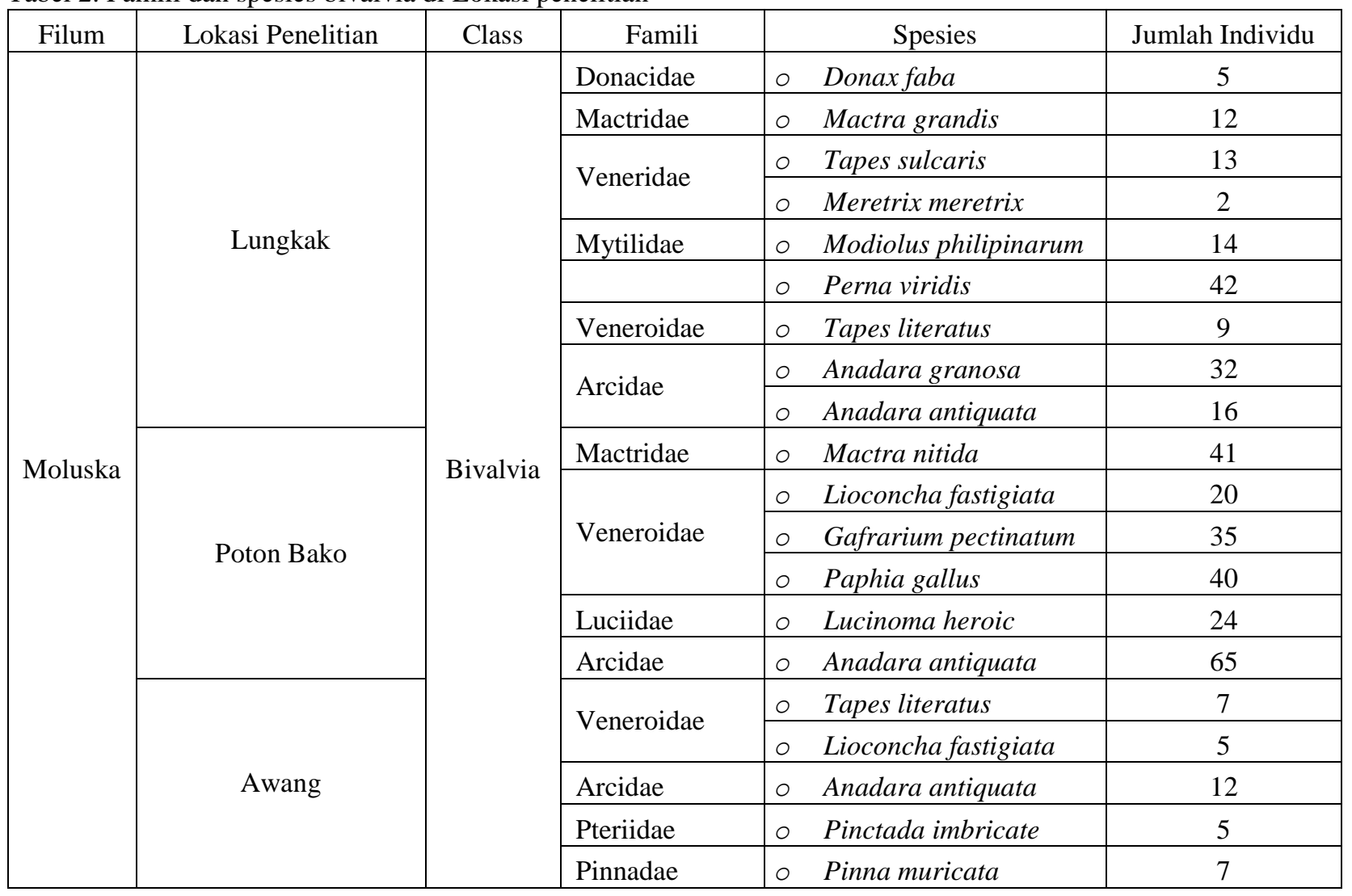

Indeks keanekaragaman (H') di ketiga lokasi penelitian tergolong rendah, indeks keseragaman (E) tergolong tinggi dan indeks dominansi (D) tergolong rendah atau tidak ada. Ketiga nilai indeks tersebut disajikan pada (Gambar 5).

Berdasarkan perhitungan indeks keanekaragaman (H') diperoleh keanekaragaman tertinggi terdapat di 
Pantai Lungkak dengan nilai 1.705 sehingga tergolong rendah. Indeks keseragaman (E) tertinggi di Pantai Awang dengan nilai 0,96 sehingga tergolong kategori tinggi. Indeks dominansi relatif diperoleh dominansi tertinggi di Pantai Lungkak dengan nilai $0.11 \%$ yang tergolong kategori rendah yang berarti tidak ada spesies bivalvia yang mendominasi.

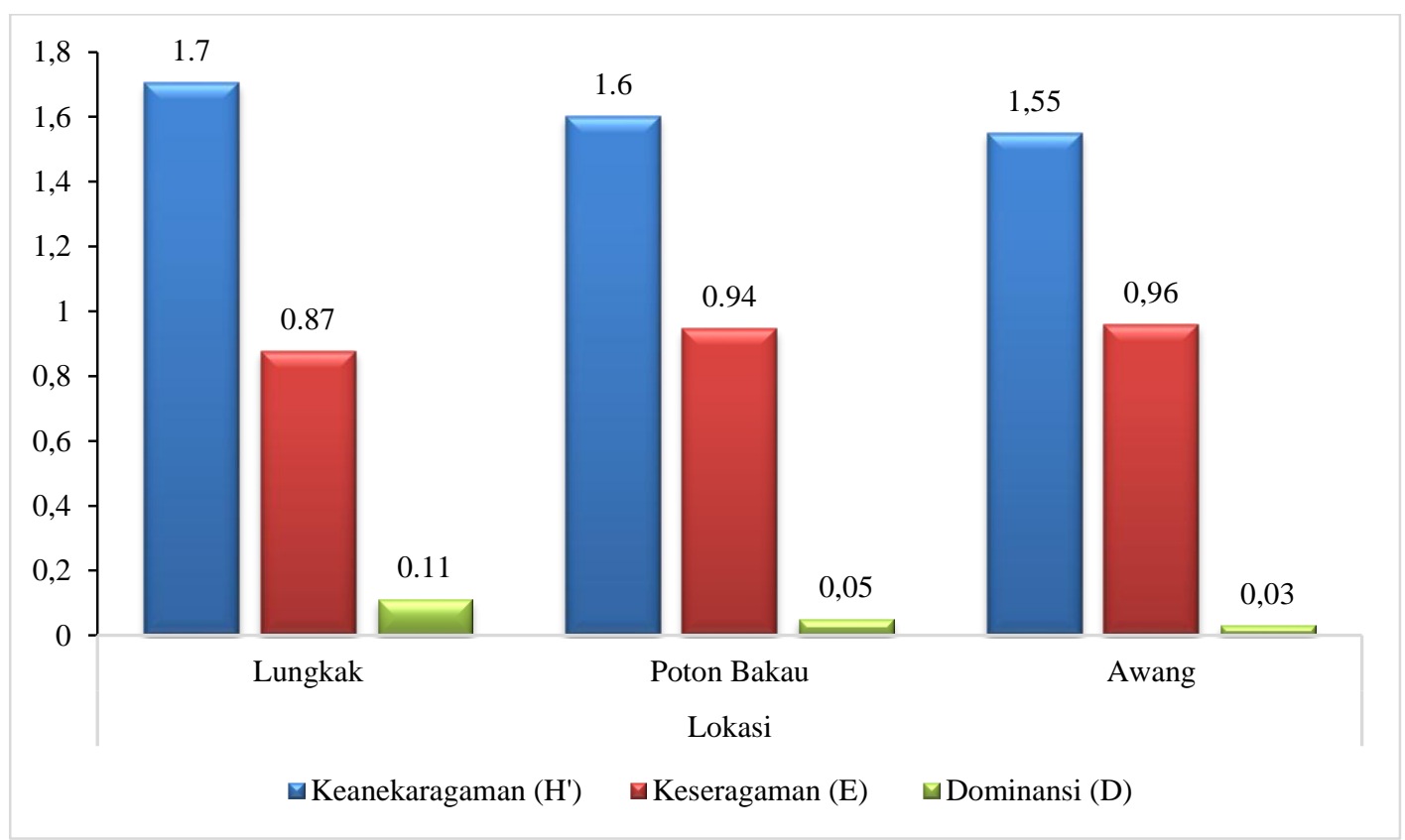

Gambar 5. Indeks Ekologi Bivalvia di Lokasi penelitian

Nilai indeks keanekaragaman Bivalvia yang ditemukan pada lokasi penelitian sama dengan nilai indeks keanekaragaman yang ditemukan pada kawasan Pangkep, Sulawesi Selatan memiliki indeks keanekaragaman dengan kisaran 1.81 dalam kategori rendah (Hamsiah, et al., 2016) dan di perairan Kundalika, India memiliki keanekaragaman sebesar 1.1 (Sunil dan Priyanka. 2017). Sedangkan di Mexico dengan keanekaragaman sebesar 3.65 yang tergolong tinggi terkait dengan cakupan wilayah yang luas untuk pengambilan data (Garza et al., 2014).

Nilai indeks keanekaragaman Bivalvia pada ketiga lokasi penelitian (Gambar 4) tidak jauh berbeda salah satunya disebabkan oleh variasi substrat dasar perairan. Pada ketiga lokasi penelitian memiliki variasi substrat dasar perairan yang sama yakni bersubstrat lumpur, lumpur berpasir, dan pasir berlumpur. Variasi substrat yang sama antara ketiga lokasi penelitian menyebabkan jumlah individu masing-masing spesies Bivalvia yang ditemukan tidak jauh berbeda, sehingga indeks keanekaragaman spesies pada ketiga lokasi penelitian tidak berbeda secara signifikan. Hal tersebut sesuai dengan Pancawati et al (2014) yang menyatakan bahwa substrat dasar merupakan salah satu faktor yang dapat mempengaruhi penyebaran makrozoobentos, Echinodermata dan bivalvia, karena selain berperan sebagai tempat tinggal juga berfungsi sebagai penimbun unsur hara (sebagai media penyedia sumber makanan), tempat berkumpulnya bahan organik serta tempat perlindungan organisme dari ancaman predator.

Nilai indeks Keseragaman menunjukkan pola sebaran individu pada suatu lokasi. Jika indeks keseragamannya semakin besar maka pola sebaran individu pada suatu lokasi merata, sebaliknya jika nilai indeks keseragamannya semakin kecil menujukkan pola sebaran individu yang tidak merata. Nilai indeks keseragaman yang diperoleh di lokasi penelitian adalah berkisar antara 0,87 - 0,96 dan termasuk dalam kategori tinggi. Nilai indeks keseragaman yang diperoleh dari ketiga lokasi penelitian menunjukkan bahwa pola sebaran spesies pada lokasi penelitian cukup merata yang menunjukkan bahwa tidak ada spesies yang mendominasi.

Berdasarkan hasil pengolahan data indeks dominansi diperoleh nilai tertinggi di Pantai Lungkak dengan nilai 0.11 yang tergolong kategori rendah yang berarti tidak ada jenis yang mendominasi. Adanya dominansi menunjukkan kondisi lingkungan yang sangat menguntungkan dalam mendukung pertumbuhan spesies tertentu. Jika dalam suatu perairan ada jenis yang dominan, maka dalam perairan tersebut menunjukkan ada tekanan ekologis yang cukup tinggi. Akibat dari tekanan ekologis tersebut adalah kematian bagi organisme yang tidak mampu beradaptasi dan sebaliknya, bagi organisme yang mampu beradaptasi akan mengalami peningkatan jumlah yang cukup tinggi (dominan). 


\section{7) Persepsi Masyarakat Lokal tentang Ekowisata Mangrove}

Potensi ekowisata mangrove meliputi: (1) Pelestarian lingkungan atau biota laut, (2) Ekonomi, (3) Pendidikan dan (4) Mereka percaya bahwa ketiga produk ekowisata memiliki manfaat yang sama (Syukur et al, 2020). Eksplorasi pengetahuan responden sesuai topik penelitian merupakan langkah penting dalam memahami kapasitas responden sebagai informan yang representative. Hasil wawancara dan analisis, kategori responden dalam hal ini berdasarkan kategori umur. Umur responden yang diwawancarai secara acak, ternyata yang terbanyak yaitu antara 30-45 tahun yang merupakan usia produktif sebesar $61 \%$, diikuti oleh yang berumur dibawah 30 tahun sebanyak 22\% dan diatas 45 tahun sebanyak $17 \%$ (Gambar 6).

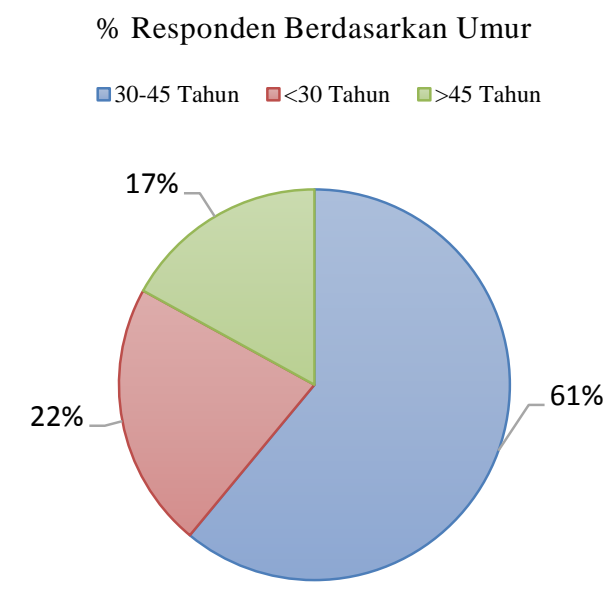

Gambar 6. Persentase responden berdasarkan umur

a. Persepsi Masyarakat Apakah Ekosistem Mangrove di Lokasi Penelitian Memiliki Potensi Untuk Dikembangkan

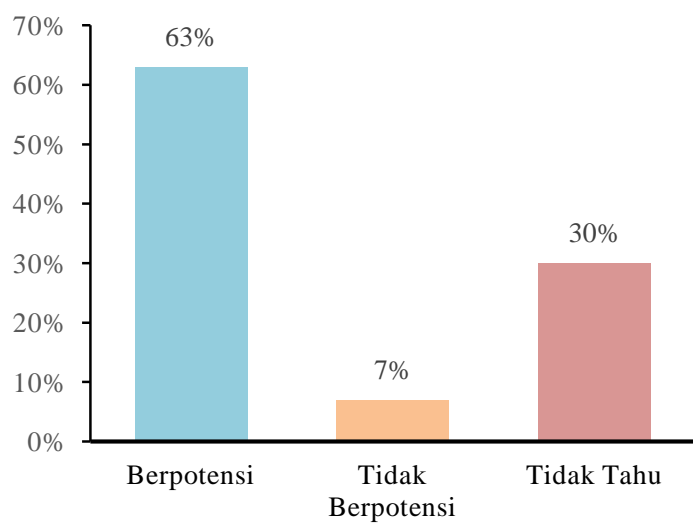

Sumber: Data Primer (kuisioner) 2021
Gambar 7. Persepsi masyarakat mengenai apakah ekosistem mangrove memiliki potensi untuk dikembangkan.

Gambar 7 menunjukkan bahwa sebanyak 63 persen responden mengatakan bahwa ekosistem mangrove berpotensi untuk dikembangkan, karena mangrove yang ada di Pantai Lungkak dan Poton Bako dekat dengan objek wisata Gili Pasir Putih yang juga merupakan spot wisata yang saat air laut surut maka akan membentuk daratan dengan banyak biota melimpah seperti Echinodermata dan Bivalvia yang endemik seperti Echinodermata Linckia laevigata dan Culcita sp, sehingga jika pengunjung datang berkunjung dapat juga menikmati aktivitas lain seperti menyeberang menggunakan perahu nelayan yang secara tidak langsung mendatangkan pendapatan tambahan bagi nelayan. Potensi lainnya ialah ekosistem mangrove merupakan habitat penting bagi biota laut dan sebagai penjaga pantai dari abrasi. Kemudian sebanyak 7 persen responden mengatakan bahwa ekosistem mangrove tidak berpotensi untuk dikembangkan menjadi objek wisata karena keadaan lingkungan di hutan mangrove yang belum terurus dan kondisi nya yang masih kotor. Selanjutnya, 30 persen responden mengatakan tidak tahu tentang seberapa berpotensi nya ekosistem mangrove yang ada di lokasi penelitian.

b. Persepsi Masyarakat Apakah Ekosistem Mangrove di Lokasi Penelitian Layak Dikembangkan Sebagai Kawasan Ekowisata

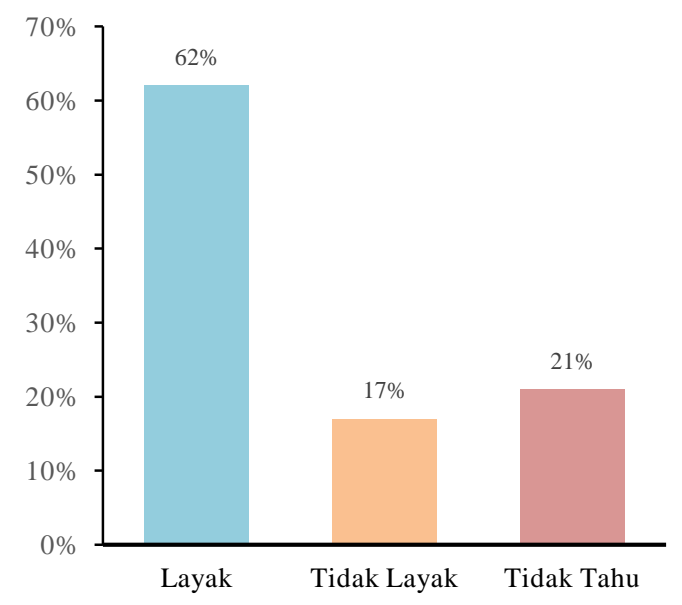

Sumber: Data Primer (kuisioner) 2021

Gambar 8. Persepsi masyarakat mengenai apakah ekosistem mangrove layak dikembangkan sebagai kawasan ekowisata.

Gambar 8 menunjukkan bahwa 62 persen responden mengatakan bahwa ekosistem mangrove layak untuk 
dikembangkan sebagai kawasan ekowisata, karena wilayah Pantai Selatan Pulau Lombok memiliki hutan mangrove tapi tidak dikembangkan untuk aktivitas wisata. Potensi dan daya tarik pantai selatan Pulau Lombok berupa ekosistem mangrove, aliran sungai mangrove, muara sungai, pantai lungkak dan poton bako. Pengembangan ekosistem mangrove dapat berupa pembuatan spot foto berupa jembatan yang terbuat dari kayu dengan latar belakang pemandangan hutan mangrove, wisata area Outbond, Fasilitas mushola dan toilet serta tersedia makanan dan minuman Indonesian Food (Riana et al, 2020; Lelloltery et al, 2021). Sebanyak 17 persen responden mengatakan bahwa ekosistem mangrove tidak layak untuk dikembangkan sebagai kawasan ekowisata karena hutan mangrove yang berada di lokasi penelitian kurang terawat. Kemudian 21 persen responden mengatakan tidak tahu tentang hutan mangrove yang ada di lokasi penelitian.

c. Persepsi Masyarakat Mengenai Aktivitas Wisata Apa Yang Menjadi Prioritas Pengembangan

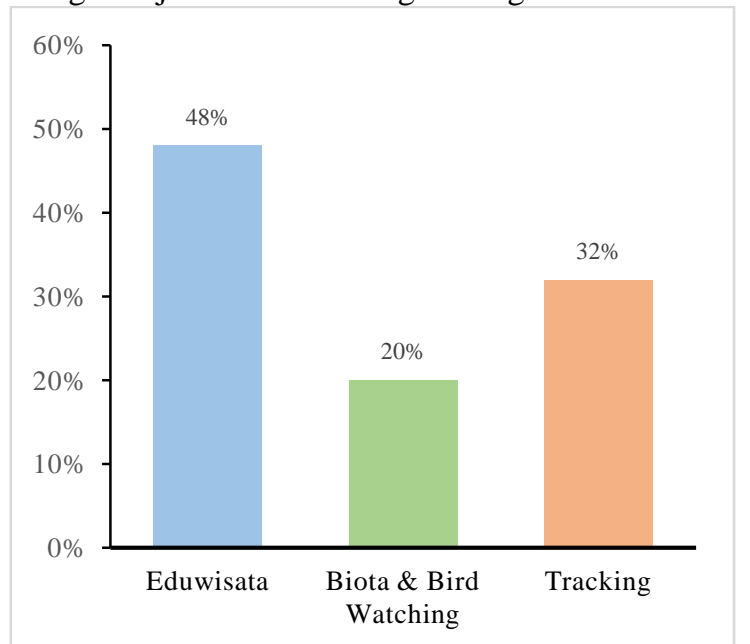

Sumber: Data Primer (kuisioner) 2021

Gambar 9. Persepsi masyarakat mengenai aktivitas wisata apa yang menjadi prioritas pengembangan.

Gambar 9 menunjukkan bahwa 48 persen responden mengatakan bahwa aktivitas wisata yang paling didukung untuk dikembangkan adalah eduwisata karena warga di tempat tersebut lebih mengetahui kegiatan aktivitas yang sering dilakukan oleh masyarakat dari luar Desa adalah kegiatan penelitian dan Praktikum lapangan sehingga masyarakat lokal yang melihat kunjungan tersebut juga ingin mengetahui apa yang sedang dilakukan oleh pengunjung Pantai Lungkak dan Poton Bako. Sedangkan 20 persen responden mengatakan bahwa biota seperti Echinodermata dan Bivalvia, serta spot bird watching perlu di kembangkan karena dapat mempelajari biota yang berasosiasi dengan mangrove, serta burung - burung yang unik dan menarik yang hidup di hutan mangrove. Selanjutnya, 32 persen responden memilih agar aktivitas mangrove tracking di kembangkan, karena sambil berjalan - jalan Bersama keluarga dapat menikmati dan mempelajari berbagai hal mengenai jenis - jenis tumbuhan hutan mangrove.

d. Persepsi Masyarakat Mengenai Setujukah Jika Aktivitas Wisata Di Mangrove Ini Dikembangkan

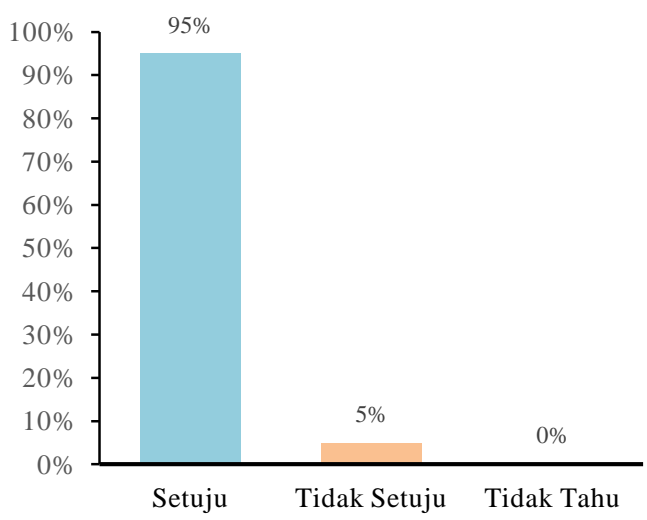

Sumber: Data Primer (kuisioner) 2021

Gambar 10. Persepsi Masyarakat mengenai pengembangan aktivitas wisata di mangrove di Lungkak, Poton Bako, dan Awang

Gambar 10 menunjukkan bahwa sebanyak 95 persen responden di Wilayah Pantai Selatan Pulau Lombok mengatakan bahwa setuju jika aktivitas di Mangrove ini dikembangkan, karena dapat menjadi objek wisata baru yang dapat menarik para pengunjung/wisatawan lokal bahkan mancanegara dan juga dapat memberikan pendapatan untuk masyarakat setempat. Sedangkan 5 persen dari responden di lokasi penelitian mengatakan tidak setuju, karena tempatnya masih kotor, banyak pengunjung yang datang tapi membuang sampah sembarangan.

Ekowisata merupakan kegiatan wisata yang bertumpu pada pelestarian sumber daya alam. Dalam hal ini, keanekaragaman hayati yang menyediakan jasa ekosistem yang aman dan terjamin ketika orang melindunginya. Dalam hal ini, konservasi keanekaragaman hayati dan ekosistemnya memiliki hubungan langsung dengan peningkatan mata pencaharian masyarakat lokal dan upaya rehabilitasi habitat merupakan solusi bagi penghidupan masyarakat setempat. Sementara itu, hasil wawancara, diskusi mendalam, focus group discussion menunjukkan bahwa keberadaan lembaga masyarakat setempat belum memainkan peran optimal dalam pengelolaan mangrove. 
Namun demikian nilai-nilai pemahaman mereka tentang mangrove secara individual adalah kekuatan utama dalam menjaga keberlanjutan mangrove di lokasi penelitian.

Perilaku masyarakat setempat terhadap keberadaan mangrove merupakan modal sosial yang sangat penting bagi keberhasilan konservasi mangrove di lokasi penelitian. Selain itu, masyarakat setempat yang memiliki hubungan simbiosis dengan hutan dapat menjadi mitra dalam upaya pengembangan hutan (Agbogidi et al., 2010). Hal utama yang berkaitan dengan hal ini adalah mata pencaharian adalah faktor utama sebagai motivasi dalam partisipasi mereka untuk restorasi dan pengelolaan mangrove. Namun, mereka yang memiliki penghasilan rendah dapat diberikan pendampingan agar tidak melakukan reexploitasi sumber daya mangrove (Aheto et al., 2016). Mengidentifikasi dan menerapkan pendekatan berdasarkan karakteristik lokal dapat meningkatkan keberhasilan konservasi melalui restorasi habitat mangrove (Romanach et al., 2018), dan hubungan masyarakat dengan sumber daya ekosistem mangrove dapat dikapitalisasi dalam kebijakan pengelolaan mangrove (My \& Takeda, 2015); Shuib et al., 2012). Selain itu, strategi konservasi dengan mengintegrasikan sistem tradisional masyarakat lokal dapat dikembangkan untuk tujuan konservasi (Arthur \&Vladimir, 2015).

Keberhasilan pengembangan kawasan mangrove harus berdasarkan opini masyarakat. Dalam perspektif ini, masyarakat setempat membutuhkan informasi, terutama tentang mata pencaharian mereka yang berasal dari ekosistem mangrove (Wever et al., 2012). Namun, fakta tentang tren degradasi mangrove masih sulit dihentikan dan pemulihan mangrove akan tergantung pada kebijakan yang menyeimbangkan prioritas tujuan sosial dan ekologis (Chowdhury et al., 2017). Selain itu, diperlukan perubahan manajemen mengenai konsep kepemilikan bersama untuk memastikan partisipasi dalam praktik konservasi (Roy et al., 2013). Salah satu strategi dalam konservasi mangrove adalah melalui penanaman dan sekaligus pengelolaannya terintegrasi dengan kebutuhan masyarakat setempat (Hamilton \& Collins, 2013; de Oliveira et al., 2018).

\section{Kesimpulan}

Pemanfaatan lingkungan pesisir masih didominasi oleh produk dan belum beralih ke produk jasa ekosistem, seperti pemanfaatan ekosistem mangrove sebagai ekowisata. Mangrove di lokasi penelitian didominasi Avicennia marina, Ceriops decandra, Rhizophora mucronata, Rhizophora stylosa, Sonneratia alba, dan Xylocarpus moluccensis. Persepsi masyarakat terhadap konservasi mangrove untuk keberlanjutan ekowisata, $63 \%$ masyarakat menyatakan berpotensi, $7 \%$ Tidak Berpotensi dan $30 \%$ tidak tahu. Tingkat Layak mangrove untuk dikembangkan sebesar $62 \%$, tidak layak
$17 \%$ dan tidak tau 21\%. Prioritas yang ingin dikembangkan berupa eduwisata $48 \%$, Biota and Bird Watching 20\% dan Tracking 32\%. Hal lain yang berpengaruh terhadap keberlanjutan ekowisata ialah kesadaran masyarakat lokal terhadap pelestarian lingkungan. Salah satu strategi dalam konservasi adalah melalui penanaman dan pengelolaan terintegrasi dengan kebutuhan masyarakat lokal.

\section{Ucapan Terima Kasih}

Terima kasih kepada Direktur Pascasarjana dan ketua program studi Magister Pendidikan IPA Universitas Mataram. Ucapan terima kasih juga disampaikan kepada Dosen Pengampu Mata Kuliah Studi Mandiri atas bimbingannya, serta pihak lain yang berkontribusi secara signifikan.

\section{Referensi}

Agbogidi, O. M., Ofuoku, A. U., \& Dolor, D. E. (2010). Role of community Forestry in sustainable forest Management and Development: a Review. ASSET: An International Journal (Series A), 7(1): 44-54.

Al Idrus, A., Hadiprayitno G, Hamdi L \& Mertha IG. (2014). Inveltarisasi Flora dan fauna di Kawasan Mangrove Gili Sulat untuk Pengembangan Bahan Ajar Ekologi dan Penunjang Pariwisata. Loporan Penelitian. Lembaga Penelitian Universitas Mataram.

Al Idrus, A., Hadiprayitno G, Hamdi L \& Mertha IG. (2015). Potensi Vegetasi dan Arthropoda diKawasan Mangrove Gili Sulat Lombok Timur. Biologi Tropis, 15(2): 62-70.

Al Idrus, A., Kesipudin, K., \& Mertha, I. G. (2018). Aplikasi Konsep Konservasi Mangrove Untuk Pengembangan Ekowisata Di Pantai Selatan Lombok Timur. Jurnal Pendidikan dan Pengabdian Masyarakat, 1(1).

Aheto, D. W., Kankam, S., Okyere, I., Mensah, E., Osman, A., Jonah, F. E., \& Mensah, J. C. (2016). Community-based mangrove forest management: Implications for local livelihoods and coastal resource conservation along the Volta estuary catchment area of Ghana. Ocean \& coastal management, 127: 43-54.

Akhrianti, I.D.G. (2014). Distribusi Spasial dan Preferensi Habitat Bivalvia di pesisir Perairan Kecamatan Simpang Pesak Kabupaten Belitung Timur. Jurnal Ilmu dan Kelautan Tropis. 6 (1): 171-185. 
Al Idrus, A., Kesipudin, K., \& Mertha, I. G. (2018). Aplikasi Konsep Konservasi Mangrove Untuk Pengembangan Ekowisata di Pantai Selatan Lombok Timur. Jurnal Pendidikan dan Pengabdian Masyarakat, 1(1)

Alfiannur, M., Rahman, M., \& Rahman, A. (2018). Hubungan Indeks Komunitas Makrozoobenthos Dengan Parameter Kualitas Air Di Sungai Martapura Desa Melayu Kabupaten Banjar Provinsi Kalimantan Selatan. Aquatic, 1(1), 33-47.

Alfiansyah, A., H. Irawan \& F. Yandri (2017). Struktur Komunitas Bivalvia di Lamun di Perairan Teluk Dalam. Fakultas Ilmu Kelautan dan Perikanan. UMRAH. Batam.

Allen, JA. (2013). Bivalvia terkini: bentuk dan evolusinya. The mollusca, 10, 337-403.

Arsad, S., Daryanto, A. O., Sari, L. A., Saputra, D. K., \& Pratiwi, F. D. (2021). Community-Based Ecotourism and Its Impact on the Social and Economic Conditions: A Case Study in Blekok, Situbondo Regency, Indonesia. Journal of Environmental Management and Tourism, 12(3), 797-807.

Arthur, B., \& Vladimir, R. (2015). Socio-Ecological and Livelihood Assessment of Selected Coastal Areas in Sorsogon, Philippines. International Journal on Advanced Science, Engineering and Information Technology, 5(4): 339-343.

Ascher, W. (1995). Communities and Sustainable Forestry in Developing Countries. Institute for contemporary, San Francisco, USA.

Bahri, S., Patech, L. R., Zulhalifah, Z., Septiani, D. A., \& Siswadi, S. (2021). Distribution and Diversity of Echinoderms in the Coastal Waters of South Beach of Lombok Island. Jurnal Biologi Tropis, 21(1), 22-31.

Bengen, D.G., (2002). Pedoman Teknis. Pengenalan Dan Pengelolaan Ekosistem

Bengen, D.G., (2003). Pengenalan Dan Pengelolaan Ekosistem Mangrove.Pedoman

Bismark M \& R. Sawitri. (2010). Kelimpahan dan Keragaman Spesies Plankton di Hutan Mangrove, Pulau Siberut. Info Hutan, VII (1): 77-87.

Bronstein, O. \& Y. Loya, (2014). Echinoid community structure and rates of herbivory and bioerosion on exposed and sheltered reefs. Journal of Experimental Marine Biology and Ecology 456: 8-17

Cahyanto, T., \& Kuraesin, R. (2013). Struktur Vegetasi
Mangrove di Pantai Muara Marunda Kota Administrasi Jakarta Utara Provonsi DKI Jakarta. Jurnal Istek. 7(2): 73-88.

Cannicci, S., Burrows, D., Fratini, S., Smith III, T.J., Offenberg, J., \& Dahdouh-Guebas, F., (2008). Faunistic impact on vegetation structure and ecosystem function in mangrove forests: A review. Aquatic Botany, 89: 186-200.

Candri, D. A., Sani, L. H., Ahyadi, H., \& Farista, B. (2020). Struktur komunitas Moluska di kawasan mangrove alami dan rehabilitasi pesisir selatan Pulau Lombok. Jurnal Biologi Tropis, 20(1), 139147.

Castro, R. A., Quecine, M. C., Lacava, P. T., Batista, B. D., Luvizotto, D. M., Marcon, J., ... \& Azevedo, J. L. (2014). Isolation and enzyme bioprospection of endophytic bacteria associated with plants of Brazilian mangrove ecosystem. Springer Plus, 3(1): 1-9.

Chowdhury, R. R., Uchida, E., Chen, L., Osorio, V., \& Yoder, L. (2017). Anthropogenic Drivers of Mangrove Loss: Geographic Patterns and Implications for Livelihoods. In Mangrove Ecosystems: A Global Biogeographic Perspective, 275-300.

Christian, Y., Budiman, M. K., Purwanto, W., \& Damar, A. (2021, April). Supporting community-based mangrove forest management as Essential Ecosystem Area in Sungai Pakning, Riau. In IOP Conference Series: Earth and Environmental Science (Vol. 744, No. 1, p. 012007). IOP Publishing.

Claoue', C., T. Hodges, T. Hill, W. Blyth \& D. Easty, (1988). Neural spread of herpes simplex virus to the eye of the mouse: microbiological aspects and effect on the blink reflex. Eye (Basingstoke) 2: 318-323

de Oliveira Côrtes, L. H., Zappes, C. A., \& Di Beneditto, A. P. (2018). MThe crab harvest in a mangrove forest in south-eastern Brazil: Insights about its maintenance in the long-term. Perspectives in ecology and conservation, 16 (2): 113-118.

Dewi, I. K., Suwarti, S., \& Yuwanti, S. (2021). Pengenalan Konsep Ekowisata Dan Identifikasi Potensi Wisata Alam Berbasis Ekowisata. Selaparang Jurnal Pengabdian Masyarakat Berkemajuan, 4(2), 307-314.

Direktorat Jenderal Bina Pesisir (2004). Pedoman Penetapan Kawasan Konservasi Laut Daerah (KKLD). Departemen Kelautan dan Perikanan. Jakarta 
Ehler C, Stefano B \& Billiana CS. (2004). In Corporating Marine Protected Areas into Integrated Coastal and Ocean Management: Principle and Guidelines. IUCN. United Kingdom Ingris.

Ellison A M. (2008). Mangrove ecology - applications in forestry and costal zone management. Aquatic Botany, (89): 77.

Few R. (2009). Conservation, Participation, and Power: Protected-Area Planning in the Coastal Zone of Belize. Journal of Planning Education and Research. 19: 410 - 408.

Friess, D. A. (2017). Ecotourism as a tool for mangrove conservation. Sumatra Journal of Disaster, Geography and Geography Education, 1(1): 2435.

Friess, D. A., Yando, E. S., Abuchahla, G. M., Adams, J. B., Cannicci, S., Canty, S. W., ... \& Wee, A. K. (2020). Mangroves give cause for conservation optimism, for now. Current Biology, 30(4), R153R154.

Garza-Flores, R., López-Rojas, V., Flores-Rodríguez, P., \& Ramírez, C. T. (2014). Diversity, distribution and composition of the bivalvia class on the rocky intertidal zone of marine priority region 32 , Mexico. Open Journal of Ecology, 4(15), 961.

Gilpin A. (1996). Dictionary of Environment and Sustainable Development. John Wiley dan Sons. Singapore.

Hakim, L., Siswanto, D., \& Makagoshi, N. (2017). Mangrove conservation in East Java: the ecotourism development perspectives. Journal of Tropical Life Science, 7(3): 277-285.

Hamilton, S. E., \& Collins, S. (2013). Livelihood responses to mangrove deforestation in the northern provinces of Ecuador. Bosque, 4(2): 143153.

Harto, S., Sidiq, R. S. S., \& Karneli, O. (2021). Development Strategy Mangrove Ecotourism based on Local Wisdom. Sosiohumaniora, 23(1), 115-123.

Hermosillo-Núñez, B. B. (2020). Contribution of echinoderms to keystone species complexes and macroscopic properties in kelp forest ecosystems (northern Chile). Hydrobiologia, 847(3), 739-756.

Hiariey. L.S. (2009). Identifikasi Nilai Ekonomi Ekosistem Hutan Mangrove di Desa

Julaikha, S., \& Sumiyati, L. 2017. Nilai Ekologis Ekosistem Hutan Mangrove. Jurnal Biologi Tropis. 17(1): 23-31.
Karimah, K. 2017. Peran Ekosistem Hutan Mangrove sebagai Habitat untuk Organisme Laut. Jurnal Biologi Tropis. 17(2): 51-57.

Khan, S. U., Khan, I., Zhao, M., Khan, A. A., \& Ali, M. A. S. 2019. Valuation of ecosystem services using choice experiment with preference heterogeneity: a benefit transfer analysis across inland river basin. Science of the Total Environment, 679: 126135 .

Khordi K, M. \& Ghufran H. 2012. Ekosistem Mangrove Potensi, Fungsi, dan Pengelolaan. Jakarta: Rineka Cipta.

Kitamura, S., C. Anwar, A. Chaniago and S. Baba. (1997). Handbook of Mangroves in Indonesia, Bali \& Lombok. The Development of sustainable Mangrove Management Project, Ministry of Forestry Indonesia and Japan International Cooperation Agency. Jaya Abadi, Denpasar, Bali.

Larkum AWD. Robert JO \& Carlos M. Duarte. (2006). Seagrasses: Biology, Ecology and Conservation. Springer. Netherlands.

Lelloltery, H., Rumanta, M., \& Kunda, R. M. (2021). Strategy for marine ecotourism development based on natural resource management: Case study in Kotania Bay, Western Seram District, Maluku, Indonesia. Nusantara Bioscience, 13(1).

Lina, F. Lestari \& A. Zulfikar. (2015). Struktur Komunitas Gastropoda di Ekosistem mangrove Sungai Nyirih Kecamatan Tanjung Pinang Kota Tanjung Pinang. Jurnal Elektronik. 1-15.

Litiloly, L. I., Mardiatmoko, G., \& Pattimahu, D. V. (2020). Analysis of Mangrove Forest Economic In Kotania Bay, West Seram District. Jurnal Hutan Pulau-Pulau Kecil, 4(1), 22-30.

Llacuna, M.E.J., Walag, A.M. \& Elaine A. Villaluz, E.A. (2016). Diversity and dispersion patterns of echinoderms in Babanlagan, Talisayan, Misamis Oriental, Philippines. Environmental and Experimental Biology 14 (1): 213-217.

Lowery, J. L., Paynter Jr, K. T., Thomas, J., \& Nygard, J. (2007). The importance of habitat created by molluscan shellfish to managed species along the Atlantic Coast of the United States. Washington, DC: Atlantic States Marine Fisheries Commission.

Malik, A., Mertz, O., \& Fensholt, R. (2017). Mangrove Forest Decline: Consequences for Livelihoods and Environment in South Sulawesi. Regional Environmental Change, 17(1): 157-169.

Massiseng, A. N. A., Tuwo, A., Fachry, M. E., \& Bahar, A. (2020). A dynamic simulation of mangrove 
ecotourism management at the Lantebung of Makassar City. In IOP Conference Series: Earth and Environmental Science, 584(1): 1-11.

My, H. H. T., \& Takeda, S. (2015). Decentralization in Mangrove Restoration: a Critical Analysis-Case study in Central Coast of Vietnam. In $A n$ international academic conference, Chiang Mai University: Land grabbing, conflict and agrarianenvironmental transformation: perspectives from East and Southeasy Asia. Conference Paper, 50(17).

Nagelkerken, I., Blaber, S.J.M., Bouillon, S., Green, P., Haywood, M., Kirton, L.G., Meynecke, J.-O., Pawlik, J., Penrose, H.M., Sasekumar, A., Somerfield, P.J., (2008). The habitat function of mangroves for terrestrial and marine fauna: A review. Aquatic. Botany. 89: 155-18

Odum, E. P. (1996). Basics of Ecology Third Edition. Samingan, T (translator). Yogyakarta: Gadjah Mada University Press.

Ortiz, M. \& R. Levins, (2011). Re-stocking practices and illegal fishing in northern Chile (SE Pacific coast): a study case. Oikos 120: 1402-1412.

Pancawati, D.K., D. Suprapto, \& P.W. Purnomo. (2014). Karakteristik Fisika Kimia Perairan Habitat Bivalvia di Sungai Wiso Jepara. Diponegoro Journal of Marques, 3(4): 141-146.

Patech, L. R., Syukur, A., \& Santoso, D. (2020). Kelimpahan dan Keanekragaman Spesies Echinodermata sebagai Indikator Fungsi Ekologi Lamun di Perairan Pesisir Lombok Timur. JURNAL SAINS TEKNOLOGI \& LINGKUNGAN, 6(1), 40-49.

Pauly D. and Ingles J. (1986). The relationship between shrimp yields and intertidal vegetation (mangrove) areas: area ssessment. In IOC/FAO Workshop on Recruitment in Tropical Coastal Demersal Communities. Unesco Paris, pp.227- 284.

Priyatna FN, Nasution Z, Satrawijaya, Hartono TT \& Mursidin (2007). Sosial Budaya Masyarakat Nelayan: Konsep dan Indikator Pemberdayaan.Badan Riset Kelautan dan Perikanan, Departemen Kelautan dan Perikanan. I $-29$.

Raghunathan C, Venkataraman K. "Diversity of Echinoderms in Rani Jhansi". Jouranls of Marine National Park, Andaman and Nicobar Islands. International Day for Biodiversity. 1 (1) : 22-40.

Riana, A., Pianti, D. O., Ramadhila, R., Pranata, Y., \& Nata, P. R. (2020). Potensi Hutan Mangrove
Sebagai Ekowisata Bagi Masyarakat Pesisir Bengkulu. ISEJ: Indonesian Science Education Journal, 1(3), 210-215.

Romañach, S. S., DeAngelis, D. L., Koh, H. L., Li, Y., Teh, S. Y., Barizan, R. S. R., \& Zhai, L. 2018. Conservation and restoration of mangroves: Global status, perspectives, and prognosis. Ocean \& Coastal Management, 154: 72-82.

Roy, A.K.D., Alam, K., and Gow, J. 2013. Community perceptions of state forest ownership and management: A case study of the Sundarbans Mangrove Forest in Bangladesh. Journal of Environmental Management 117: 141-149.

Sandifer, P. A., Sutton-Grier, A. E., \& Ward, B. P. 2015. Exploring connections among nature, biodiversity, ecosystem services, and human health and wellbeing: Opportunities to enhance health and biodiversity conservation. Ecosystem services, 12: $1-15$.

Satria A. (2006). Sawen institution, local knowledge in fisheries management in North Lombok, Indonesia. Fisher Knowledge in Fisheries Science and Management. UNESCO: $197-218$.

Senoaji, G., \& Hidayat, M. F. (2016). Peranan Ekosistem Mangrove Di Kota Pesisir Bengkulu Dalam Mitigasi Pemanasan Global Melalui Penyimpanan Karbon (the Role of Mangrove Ecosystem in the Coastal City of Bengkulu in Mitigating Global Warming Through Carbon Sequestration). Jurnal Manusia dan Lingkungan. 23(3): 327-333.

Shuib, A. H. M. A. D., Yee, L. S., \& Edman, S. A. L. B. I. A. H. (2012). Attitudes of local communities towards conservation of the mangrove ecosystem in Kuching, Sarawak. The Malaysian Forester, 75: 15-28.

Smith, T.M., \& Smith, R.L. (2011). Elements of Ecology $8^{\text {th }}$ Edition. USA: Pearson Education.

Steneck, R. S., M. H. Graham, B. J. Bourque, D. Corbett, J. M. Erlandson, J. A. Estes \& M. J. Tegner, (2018). Kelp forest ecosystems: biodiversity, stability, resilience and future. Environmental Conservation 29: 436-459.

Sulistiyowati, H. (2009). Biodiversitas Mangrove Di Cagar Alam Pulau Sempu. Jurnal Sainstek. 8(1): 59-63.

Sunil Khade, N., \& Priyanka Khade, S. (2017). Marine Molluscan diversity and statistical analysis of Kundalika estuary, Coast of India. International Journal of Entomology Research, 2(1), 20-23.

Susanto H A. (2011). Progres pengembangan sistem 
kawasan konservasi peraiaran Indonesia. USAID Project: 1-48.

Syukur, A., Al-Idrus, A., \& Zulkifli, L. (2020). Ecotourism development based on the diversity of echinoderms species in seagrass beds on the south coastal of Lombok island, Indonesia. Journal of Environmental Science and Technology, 13(2), 57-68.

Undang-Undang Republik Indonesia Nomer 5 Tahun 1990 tentang Konservasi Sumberdaya Alam Hayati dan Ekosistemnya. Lembaran Negara Tahun 1990 Nomer 49. Tambahan Lembran Negaran Nomer 3419

Wever, L., Glaser, M., Gorrism, P., and Ferrol-Schulte, D. (2012). Decentralization and participation in integrated coastal management: Policy lessons from Brazil and Indonesia. Ocean \& Coastal Management, 66: 63-72.

Yuliana, E., \& Supriono, E. (2020). Pengelolaan Ekowisata Mangrove Berdasarkan Daya Dukung Ekosistem dan Persepsi Masyarakat. Jurnal Matematika Sains dan Teknologi, 21(1): 48-60.

ZULHAlIFAH, Z., Syukur, A., Santoso, D., \& KARNAN, K. (2021). Species diversity and composition, and above-ground carbon of mangrove vegetation in Jor Bay, East Lombok, Indonesia. Biodiversitas Journal of Biological Diversity, 22(4). 